\title{
Gifts, trips and Facebook families: children and the semiotics of kinship in transnational Senegal
}

\author{
Chelsie Yount-André
}

Scholarship on transnational families has regularly examined the material resources that adults abroad send to children living in their country of origin (Hondagneu-Sotelo and Avila 1997; Schmalzbauer 2001; Parreñas 2001; Coe 2011). Through an examination of transnational kinship relations among French-educated ${ }^{1}$ Senegalese urbanites, this article illuminates another permutation of this process: adults in Senegal who work to create and reinforce transnational relations with (and through) children growing up in France. Focusing on kinship relations between children in France and their family members in Senegal, this article provides insight into the everyday exchanges through which transnational families attempt to ensure the social and material reproduction of households in Africa. It analyses the evolving relationship between eleven-yearold Rama, in Paris, and Abdou, her thirty-five-year-old cousin in Dakar, who devoted substantial effort and resources to establishing close ties with his younger cousin.

Rama could count on one hand the number of times she had met Abdou, a journalist in Senegal, her parents' country of birth. Rama's father and Abdou's mother were siblings, of the same mother and father, in a family of eleven children who grew up together in Dakar. As adults, nearly all eleven had moved abroad and some had subsequently returned to Senegal. Growing up in Paris, Rama's life was separated from Abdou's by age and geographic distance. Yet, these cousins shared a special bond, materialized through Facebook messages and exchanges of, sometimes substantial, gifts.

This article analyses acts of resource redistribution that underpin transnational kinship relations, foregrounding the perspective of the French-born children of Senegalese migrants. ${ }^{2}$ Approaching material circulation and the transmission of cultural values as mutually imbricated processes, I demonstrate how Senegalese forge and reinforce links with certain family members, in efforts to favourably position themselves in socio-economic networks of transnational kin. I argue that, by

Chelsie Yount-André is a postdoctoral fellow in anthropology at the University of Montpellier, France, at the CIRAD research centre. She received her $\mathrm{PhD}$ in anthropology from Northwestern University and the EHESS, Paris in 2017. Her work explores economics and morality in transnational Senegalese families with a particular focus on children, language and food sharing. Email: chelsie.yount@cirad.fr

${ }^{1}$ By 'French educated', I mean individuals who received formal, francophone schooling to high school or university level in Senegal or France.

${ }^{2}$ This article is based on eighteen months fieldwork in Senegalese households in Paris (in 201415) and fifteen non-consecutive months of ethnographic research in Dakar (in 2005, 2008, 2011, 2012 and 2014). Semi-structured interviews with members of Senegalese families in Paris and Dakar complemented audio and video recordings of everyday household interactions. I also draw on child-focused methods including child-guided 'Facebook tours', drawings of children's family trees, and child-led tape recordings (Hunleth 2011). 
drawing on behaviours associated with 'cross-cousin' kinship relations, which have historically shaped marriage choices in West Africa, these transnational kin forged emergent family relations that, even in the absence of marriage, linked individuals across national borders. This cross-cousin relationship provides an example of a more general practice in which transnational families draw on and transform kinship categories that have long organized intimate and economic relations in Africa, to establish and reinforce relationships with kin abroad.

By 'Facebook family', I refer to groups of people who use the social media platform to carry out some of the everyday work of 'relating' (Carsten 2000) or 'doing family' (Morgan 1996). I trace the ways in which children in France use Facebook to maintain relationships with relatives in Senegal and examine how adult caregivers shape these relations by orchestrating material exchanges and characterizing behaviours as evidence of specific kinship relations. Senegalese adults create cultural 'scaffolding' around children, facilitating exchanges that structure and encourage children's participation in various social practices. I suggest that Facebook is particularly adapted to the work of scaffolding, in that it facilitates personalized, multigenerational exchanges in a space where youth demonstrate a sense of ease and ownership relative to their parents.

Tracing exchanges of gifts and Facebook messages among transnational family members, I explore the constraints and affordances (cf. Gibson 1979; Manning 2012; Miller et al. 2016) of Facebook as a medium of kinship-making to consider how children growing up abroad come to understand kinship with those in Senegal and the economic expectations these relations entail. I do so by paying careful attention to what I call 'economic moralities': that is, normative expectations of material obligation and entitlement (Yount-André 2017; Maurer 2009) that family members voice when interacting with kin and characterizing familial relations.

Members of transnational families draw on multiple, sometimes contradictory, ways of understanding familial relations and the material expectations they presume and entail. In Paris, Karim's kinship strategies and economic practices, for example, were guided by his desire, on the one hand, to present himself as a 'modern' individual, integrated in France, and, on the other, to favourably position himself in relations of reciprocity and exchange with kin in Senegal. An examination of everyday processes of kinship-making and the economic moralities that underpin them illustrates how individuals reinforce and transform socio-economic relations that link Senegalese across continents, reproducing households in Africa in ways that are imbricated with former European metropoles and new frontiers.

Faced with prolonged economic crisis, money and gifts sent by relatives abroad have become a critical source of support for many families in Senegal (Hannaford 2016; Buggenhagen 2012; Melly 2011; Foley 2009). Although remittances are widely regarded as one of the most reliable sources of income in this context of fiscal insecurity, flows of resources from abroad are routinely interrupted and discontinued. Economies in Europe and North America also face economic downturn, and family members in Senegal live with the fear that, over time, migrant relatives might 'forget them', meaning that their remittances slow to a stop.

Whether and how migrants - and their children - recognize kinship relations with those in Africa is critical to the material reproduction of Senegalese households. Family members in Senegal show a vested interest in the ways in which 
the next generation perceives the moral stakes of resource allocation. Children thus provide a privileged view into the uncertainty and mutability of these links, shedding light on the efforts of families in Africa to enact and maintain links with family members abroad.

A growing body of scholarship examines children and youth as agentive actors in transnational processes, focusing largely on those who have themselves migrated or, alternatively, on children 'left behind' in their parents' country of origin (Orellana et al. 2001; Coe et al. 2011; Coe 2014; Thorsen 2006; Cole and Durham 2008; Maira and Soep 2005; Hashim and Thorsen 2011; Boehem 2012). These child-focused studies have demonstrated how young people motivate adult migration and remittances, functioning as 'pivotal points' (Olwig 1999) in transnational families. Less is known about the role that children growing up abroad might play in the reproduction of transnational kinship relations. Migrants' children have historically been examined relative to questions of assimilation into the host country, and often analysed as 'second-generation' immigrants (Bankston 1998; Portes and Zhou 1993; Portes and Rumbaut 2001). This article examines the ways in which children growing up abroad may influence the social and economic practices of individuals in their parents' country of origin, both through their own agentive participation in transnational relations and as a locus of adult efforts to establish and reinforce links between individuals in Africa and abroad.

In what follows, I first examine contrasting notions of kinship relevant to members of these families in order to consider the many economic moralities that together give meaning to interactions between transnational kin. I then turn my attention to Rama's participation in her relationship with Abdou, to examine how children in France experience and understand kinship relations that span continents. Finally, I consider the ways in which Karim and Abdou structured Rama's experience of transnational kinship, analysing how Senegalese adults attempt to shape children's perceptions of kinship and the ways one 'ought to' share resources with geographically distant family members.

\section{Transnational cross-cousins}

In English, we would call Abdou and Rama 'first cousins', in French, 'cousins germains'. But in Senegal, like much of Africa, there are distinct kinship terms for 'parallel cousins', meaning the children of siblings of the same sex, and 'crosscousins', or the children of siblings of the opposite sex (Fox 1967: 185). In Wolof, one's parallel cousins are simply called 'brother' and 'sister' (mag and rakk), while the terms 'sang' and 'jamm' index a distinct relationship between cross-cousins. The word 'sang', which literally means 'master' in Wolof, suggests that matrilateral cross-cousins are the 'masters' in their relationship with their patrilateral cross-cousins, who, in turn, are their 'slaves' (jamm ${ }^{3}$ ). Rama was the daughter of Abdou's mother's brother. In Wolof, she was his 'sang'.

\footnotetext{
${ }^{3}$ The terms 'jamm-waan', meaning 'real slave' (literally kitchen slave) and jamm-lenqe (family slave) may be used to distinguish between cross-cousins and those who occupy the status of slave within the Wolof caste system (Diop 1985: 60).
} 
Rama's father Karim moved to Paris in the 1970s to go to university. He had lived in the French capital and its nearby suburbs ever since, teaching physics and chemistry in a public high school. He married Rama's mother late in life, introduced by their family members in Dakar. They lived together briefly in the suburbs of Paris, but divorced soon after Rama was born. I met Karim's exwife on multiple occasions, but had privileged access to Karim's interactions with Rama and his family members in Senegal. As the oldest of eleven siblings, Karim had hosted each of his brothers and sisters in the French capital at one time or another. Some came for brief visits while others stayed long enough to find a place of their own, embarking on their own migration journeys. Karim spoke fondly of Abdou's mother, Fama, describing her as his only little sister who lived in France and saying that she had, like him, originally moved to attend university.

At the time of my fieldwork, most of Karim and Fama's siblings were scattered throughout Europe while three lived in Dakar. Fama lived in a small city in the French Pyrenees and one of their brothers lived near Karim in a suburb of Paris. Three siblings lived in Italy and one sister in Spain. One brother was deceased and another lived, unemployed, in their family home in Dakar. Two of Karim's sisters also lived there, taking care of their ageing mother and the children of two of their sisters who lived in Europe.

Abdou was born in Dakar and raised in their family home, cared for by his maternal aunt after his mother migrated to France. At the time of my fieldwork, he lived in a separate apartment nearby. In Senegal, where the majority of jobs are located in the 'informal' sector and characterized by their precarious nature (APS 2015), Abdou's position as a journalist at a major newspaper provided him with economic security unavailable to most Senegalese. His French language skills and formal education similarly signalled his privileged class status. In Senegal, French fluency is the mark of an urban, educated elite, for whom the language provides access to salaried employment and facilitates migration abroad. Although Senegal is officially a francophone nation, Wolof serves as a common language for the vast majority of Senegalese (Versluys 2010; Cissé 2005). Instead, Wolof serves as a common language for the vast majority of urban Senegalese (Versluys 2010; Cissé 2005). Formal francophone schooling, like the language skills it teaches and necessitates, also indexes class, signalling that one's family has the means to pay school fees.

An analysis of Rama and Abdou's relationship in the context of their transnational family sheds light on everyday kinship-making processes that shape and are shaped by resource redistribution on a global scale. It demonstrates the continued salience of long-standing kinship strategies, showing how practices that have permitted Africans to weather economic volatility for centuries are now carried out, in part, through social media.

\section{Cousin marriage and 'modern' morals}

In Wolof society, as in many areas where a specific term designates cross-cousins, this relation is often described as the preferential conjugal unit. As such, women said to rank lower than their husbands in gender hierarchies - ideally marry men who are their 'slaves' in kinship terms (Diop 1985: 60-5; Moya 2017). These 
overlapping hierarchies counterbalance each other to establish a union that is, symbolically at least, egalitarian (Diop 1985: 65).

The cross-cousin relationship allows individuals to renegotiate and play with symmetry and asymmetry in their relative social roles. Rank relations among cross-cousins are often the topic of light-hearted play. Indeed, cross-cousins are known for mischievous and even profane joking relationships, which, in any other context, would cause offence (Diop 1985: 60; Radcliffe-Brown 1940; Mauss 1928; Lévi-Strauss 1945; Launay 1977; 2006). In Senegal, relationships between jamm and sang cross-cousins are said to be playful and flirtatious, founded on systematic teasing, and associated with specific obligations. On the days of religious celebrations, for example, jamm might perform the role of a slave by theatrically washing their cross-cousin's feet or helping to prepare food (Moya 2017; Diop 1985: 60).

\section{Meta-semiotics of kinship and marriage}

Asif Agha's semiotically focused approach to kinship is useful here, first for the distinction he makes between kinship terms (or kinterms) and kinship behaviours: that is, the 'behaviors performed through the use of kinterms or behaviors construed through the use of kinterms' (2007: 344). Practices such as gift giving, for example, may constitute kinship behaviours when construed through kinterms that group them alongside other practices associated with familial relations. Decoupling kinterms and kinship behaviours sheds light on the ways in which children in the Senegalese diaspora who speak no Wolof may nonetheless take part in relationships that family members in Senegal understand in the terms of Wolof kinship. Rama, for example, knew only a few phrases in Wolof and was unfamiliar with the kinship terms jamm and sang.

The distinction between kinship terms and behaviours also sheds light on the ways in which individuals improvise on and transform family relations, allowing for an analysis of emergent and metaphoric forms of kinship (or 'fictive kin') alongside conventional familial relations. Agha points out that, although individuals' actual behaviours do not always conform to the kinship norms they are thought to share, 'acquaintance with norms also makes possible effective forms of tropic improvisation' (2007: 340), through which individuals play with and reconfigure kinship norms in their efforts to achieve specific interactional aims and carry out the social work of relating.

Second, Agha's reflexive model highlights the ways in which meta-level semiotic discourses imbue kinship relations with values 'construed society-internally as a higher-order index of other facts about persons' (2007: 345, 358). He points out that the social meanings of kinship vary within each society, relative to 'social domain (practices, groups, institutional frameworks)' (ibid.: 340). As such, various familial forms come to be associated with specific groups of people, and are thought to be linked to notions of class membership, urban or rural residence, and modern versus traditional values. Agha's approach encourages a focus on the uptake or the pragmatic effects of various kinship behaviours, taking into account the possibility that the perspectives of those engaging in and interpreting the relation overlap only to a certain degree.

In Senegal, representations of cross-cousin marriage vary with socio-economic class, age and geographic location. While these unions are relatively common 
among the generational cohort of Senegalese aged fifty or older (Neveu Kringelbach 2016: 157; see also Dial 2008: 74-9), urban youth are sometimes unaware that marriage is associated with the cross-cousin relationship at all. Senegalese villagers and inhabitants of lower-class urban areas may still describe it as the ideal marriage unit (Moya 2017), but I have heard middle- and upperclass urbanites describe cross-cousin marriage as a 'traditional' practice limited to villages. In France, marriage between cousins is often associated with the bygone kinship practices of aristocratic families. In Europe and Africa alike, this type of relation can thus mark couples or entire groups as 'backward', insufficiently 'modern', or, for immigrants in France, unsuccessfully 'integrated' into French society.

Rama's father, Karim, like many Dakarois in Paris, regularly criticized African immigrants in France who arranged marriages for their children, between cousins or with partners from their parents' village. Despite Rama and Abdou's genealogical position as cross-cousins, marriage was not, to my knowledge, an explicit topic of discussion or even the subject of teasing among family members. Abdou was already married to a woman his age, whom he planned to join in Quebec the following autumn. Furthermore, Senegalese urbanites such as Abdou increasingly aspire to companionate, monogamous marriage and cross-cousin unions have become rare (Neveu Kringelbach 2016: 157).

Normative evaluations of cousin marriage as a problematic relic from the past construe this kinship practice according to a 'moral narrative of modernity' (Keane 2013; see also Latour 1993). Central to these narratives are morally charged expectations regarding kinship and how relatives 'ought' to share resources. According to these economic moralities, the emancipated modern subject should be autonomous, not indebted to far-flung kinship networks. Modern notions of kinship position the nuclear family as the basic socioeconomic unit, whereas polygyny and high fertility are associated with 'traditional' familial arrangements (Déchaux 2003; Cole 2016; Radcliffe-Brown and Forde 1950). Jennifer Cole points out that 'romantic love, companionate marriage, and the nuclear family all emerged with - and signify - modernity, while the pragmatic demands of extended families, custom and material concerns are said to characterize more traditional societies' (2016: 202). If modern marriage is ideally a pact between two individuals founded on romantic love, cross-cousin marriage rings of obligation: a strategic decision made by extended families.

Africanist scholars have pointed out that the notion that economics should ideally be separate from intimate familial relations hinges on a 'discursive and cognitive split of emotions and material resources that is particularly salient in the West' (Coe 2014: 59), but that is not relevant in many African contexts (see also Cole 2011). Cati Coe asserts that, in West Africa, 'a person's distribution of his or her resources is taken as his or her level of affection for others', in contrast to the US and Europe, where 'the distribution of material resources between family members is downplayed' (2014: 28).

Scholarship on family in Europe and the US has repeatedly demonstrated that kinship arrangements diverge significantly from idealized notions of nuclear families (Déchaux 2003; Gulløv et al. 2015; Ochs and Kremer-Sadlik 2013; Gillis 1996). But the ways in which individuals evaluate and experience kinship are nonetheless shaped by these normative images of family, institutionalized in law and everyday language. Keane explains that narratives of modernity produce a 
'largely tacit set of expectations about what a modern, progressive person, subject, and citizen, should be' (2013: 160). Failure to embody these characteristics is treated as 'an ethical failing' thought to pose a threat to individuals and entire societies. Immigrants are under particular pressure to demonstrate membership in their host country's 'community of value' (Anderson 2013) lest they be perceived as unable (or worse, unwilling) to live up to modern ideals. Immigrants' kinship practices are scrutinized as measures of their belonging in the host society.

\section{Kinship and rank-based redistribution}

In Senegal, like elsewhere in Africa, family life and resource flows are organized according to hierarchies of class and caste, gender, generation and geography. Relationships between men and women, adults and children, urbanites and villagers are explicitly characterized as asymmetric and complementary. These inequalities, in turn, drive the redistribution of resources, such that low-ranking individuals work for their superiors who should, in turn, ideally support growing numbers of dependants. Economic moralities of 'rank-based redistribution' thus presume and entail inequalities, which, in turn, direct the flow of material resources (Irvine 2001; Buggenhagen 2012).

In cross-cousin relationships, jamm (slaves) are expected to 'work' for their sang (washing their feet or helping cook), who, in turn, provide the former with gifts and support. This relation is contingent upon age, however, in that children are not expected to engage in the (often flirtatious) behaviours of cross-cousins. Overlapping hierarchies of age can sometimes reverse the direction of gifts between cross-cousins, as in the case of an adult jamm who provides a child sang with gifts, an act often interpreted as a sign of his intent to marry once she reaches adulthood.

Growing up and gaining status in Senegal are interpreted according to economic moralities of rank-based redistribution. To be an adult depends less on age than having the material means to marry, take care of children, and otherwise support dependants (Cole 2011; Bledsoe 1990; Durham 2000; 2004). Migrants similarly achieve status in Senegal by distributing money and gifts. In their transnational family, Karim's and Abdou's positions as successful adults were thus contingent on their ability and willingness to redistribute their resources.

To position oneself favourably in transnational kinship networks while simultaneously demonstrating belonging in one's host country, migrants must carefully construct their kinship relations, taking advantage of overlaps and ambiguities between diverse meanings of family. The following section analyses how European notions of kinship shape the ways in which migrants' children in France experience and understand their relationships with those in Senegal. Through an examination of the gifts and Facebook messages Rama and Abdou exchanged, I consider how transnational families navigate multiple moral frameworks to construct kinship connections.

\section{Kids' kinship and Facebook families}

The Senegalese households in which I carried out fieldwork in Paris included parents who had migrated from Dakar and between one and three children. 
Although they lived in nuclear families, these children nonetheless characterized their families as diverging from French norms, in terms of the number of recognized family members and their relatives' expectations of gifts and support. The ways in which these children understood their kinship relations often diverged from their parents' perceptions. Even those children who understood Wolof spoke of their family members using French kinship terms. Most professed ignorance when I asked about Wolof kinship relations that lacked an equivalent term in French (such as sang and jamm).

At Senegalese social gatherings in Paris, adults from Dakar regularly attempted to locate themselves relative to other Senegalese. Prodding their interlocutor's past, they searched out connections in meandering conversations that regularly uncovered long-forgotten social links and sometimes even kinship relations. Adults laughed in delight when they unearthed an unexpectedly close connection, while their children disengaged, expressing boredom with theatrical sighs. Kids responded to these discoveries with scepticism, unconvinced that their parents had stumbled on 'real' family relations.

Rama expressed ambivalence regarding her father's interpretations of family, sometimes questioning Karim's representations of kinship. For example, Karim once revealed to me that a Senegalese mother and daughter in Paris whom he had originally introduced to me as 'family friends' were in reality their distant cousins. When I asked Rama later if she was aware of this relationship, she reacted dismissively, explaining that the girl was not her 'real' cousin. In contrast to her father, who used the term 'cousin' to reflect a distant but nonetheless genealogical kinship relation, Rama interpreted this kinterm as a form of metaphorical or 'fictive' kinship.

Rama's perceptions of who constituted kin became clear when, at my request, she drew a picture of her 'family tree'. She began by confidently adding her father's siblings to the tree, hesitating only on the names of one aunt and one uncle whom she had never met. When she looked to her father for clarification, he began guiding her through their kinship connections, listing his siblings, then nieces and nephews, one by one. Rama, meanwhile, continued mapping the family tree as she saw fit, ignoring her father's genealogical list, asking him only to repeat himself when she arrived at names she was less sure of.

Karim carefully named family members and related details of their lives, while Rama quickly exhausted her knowledge of family connections and grew bored of the task. Sidestepping her father's long-winded explanations, she contented herself to write only 'grandmère' and 'grandpère' in reference to Karim's parents, resisting my suggestion that she ask her father their names. Instead of listing her cousins under the names of their parents, as she had done for herself and her own parents, Rama listed them all together at the top of the page, explaining that she had 'a lot of cousins'. She asked me multiple times if I really wanted her to list all of them, reiterating that she has a very big family.

Rama spoke of her cousins as if they made up an unwieldy list, impossible to keep track of. This dismissive portrayal contrasted with the importance she attributed to her relationship with Abdou. She hesitated before adding Abdou's name to her list of cousins, as if his inclusion on this list required explanation. 'And who else,' she wondered aloud. 'Ah, Abdou!' she remembered. Rama then paused before writing his name, specifying, 'But him, actually, he's a journalist. But he's still my cousin.' As she wrote his name next to those of cousins closer to 
her age who lived in her grandmother's home in Dakar, Rama verbally distinguished Abdou as an employed adult, only to then reiterate his genealogical status as her cousin. Indeed, Rama and her father regularly singled Abdou out among her cousins, drawing my attention to their exchanges of gifts and regular communication.

\section{'Friends' and family: the media and materiality of cultivating closeness}

My attention was first drawn to a special relationship between Rama and Abdou when Karim told me that Rama's cousin had promised to buy her an airplane ticket to Dakar during her school vacation. A testament to Abdou's desire to cultivate a relationship with his cousin, this gesture would facilitate Rama's familiarity with Dakar and her kin there. Later, when I inquired about the possible vacation in Senegal, Rama expressed doubts that the promise would materialize. Her father responded with surprise, bordering on indignation. When Rama justified herself, saying that sometimes people 'just say things like that', her father reassured her, saying that if Abdou had offered her a trip to Dakar, he would make good on his promise. Later, when I asked Karim whether he thought that Abdou would indeed buy the ticket, he suggested that it did not matter whether Abdou bought it or he (Karim) did, because Abdou could pay him back once in Senegal. Regardless of whether, in the end, it was Abdou or her father who financed the ticket, for Rama, her trip would be a gift from her cousin.

Rama described her close relationship with Abdou to me during a guided 'Facebook tour' I audio-recorded. On her Facebook page, Abdou was the first 'friend' she showed me, her attention drawn to his page by a private message he had recently sent her. She scrolled quickly through a chain of messages they had exchanged and flipped through his photographs, describing when he had posted them. She then perused her personal inbox, skipping over long chats with friends from school to show me other messages she had sent to family members abroad. Most had responded succinctly - one line of thanks to Rama's happy birthday message, for example. Others had sent no response at all.

Rama then showed me her Facebook 'wall', which included posts in which people in Senegal had 'tagged' her. By adding Rama's name to the caption of an image or article they posted, these Dakarois linked their post to her Facebook profile. She confessed that she was not always sure why they had tagged her in posts of photographs taken in Dakar or of comics about buying sheep for Tabaski, the Islamic festival Eid al-Adha. She explained that she did not know exactly how she was related to many of these young people in Dakar, but knew them to be family. Rama's Facebook exchanges with Abdou were among the most substantial and regular she had with family members. Most of her relatives who had Facebook profiles were older than her. The communication they shared was brief and indirect, unlike the personal messages she shared with Abdou.

The following July (2014), Rama and her father travelled to Senegal while I was in Dakar carrying out fieldwork. There, I was able to meet Abdou at the home of his maternal and Rama's paternal grandmother. Their large family home had many bedrooms, financed by remittances that Rama's father, Abdou's mother and their siblings had been sending from Europe since the 1970s. After introducing 
myself to Abdou, I told him that Rama had often spoken about him back in Paris. I mistakenly referred to him as her 'uncle' and Abdou kindly corrected me, saying that even if she sometimes calls him her uncle, he is actually her cousin. Having overheard my error, Rama rushed towards us, insisting that she does not mistake him for her uncle; she knows very well that he is her cousin!

Rama and her father then joined our conversation, Karim teasing her for the attention she pays her cousin and telling Abdou that Rama found him very 'classy'. Karim chuckled playfully as he described their preparation for the trip, saying that Rama had insisted on buying a special gift for Abdou. Karim teased his daughter, reporting that she 'loved Abdou so much that she wanted to spend $€ 150$ on a shirt for him'. She selected this gift because, Karim reported, she knew that he always wears chic button-down shirts. Abdou's collared shirts visibly distinguished him among their relatives in Dakar, most of whom wore T-shirts or wax-print fabrics. In the heat of Dakar's summer, Abdou's shirts, like his closed shoes, indexed his socio-economic and professional status. Among Karim's nephews in Senegal, he was the only one who held a salaried position in Dakar's formal sector.

On returning to Paris, I learned that Abdou had given Rama $€ 200$ just before she returned to France. Offered just before their interactions were again stretched across a transnational expanse, Abdou's gift appeared to be an effort to encourage Rama to remain in contact. Indeed, back in Paris, Rama spent most of the money replacing her flip-phone with a new smartphone, which allowed her to communicate with family abroad through Facebook, Skype, WhatsApp and Viber.

\section{Facebook scaffolding}

A site of regular familial exchange, Facebook fosters the kinship work I have called 'scaffolding', in which adults strategically engage children's participation in kinship activities and attribute the act of relating to the child. Borrowing from cognitive psychologists' work on language acquisition (Bruner 1978), linguistic anthropologists use the term 'scaffolding' to refer to mediating activities that social actors carry out to support 'authorized knowledge, or that information which is deemed by the community and the institution to be legitimate' (Bruna and Gomez 2009: 157). Ochs and Schieffelin (2009) provide the example of a caregiver who constructs a tower, allows a child to place the last block, and then describes the construction as the child's doing. They point out that, through the work of scaffolding, caregivers portray children to be more culturally competent than their behaviours would otherwise indicate. By celebrating children as skilful social actors, through scaffolding, adults place a tacit emphasis on behaviours they value.

Facebook is a social media platform particularly adapted to scaffolding work among transnational families: first, because it is a multigenerational platform that fosters kinwork; and second, because children demonstrate a sense of ease and ownership on the site. While Facebook's most avid users were young people, among the Senegalese with whom I carried out my fieldwork, the site's user base was undergoing a generational shift. Parents in their forties and fifties were increasingly creating profiles and joining their children on the site. As such, Facebook was a space of intergenerational interactions where children had direct access to international family members. 
As the site's popularity has extended across age cohorts (see Miller et al. 2016), interactions with family members have become an increasingly important use of the platform. The site has developed to foster this engagement, encouraging users to signal who among their 'friends' are family members. Unlike Twitter or Instagram, where one might create a public profile that reveals little about one's family life, Facebook encourages users to create a personal profile, sharing information on their relationships and announcing events such as marriages and births. Miller and his colleagues (ibid.) have documented the ways in which Facebook users internationally use the platform to consciously perform family ties and to connect with distant relatives they may have never met face to face.

In Facebook-mediated kinship relations, children possess particular agency as a result of their familiarity with and regular use of the site. In most cases, the children I worked with had joined Facebook before their parents. Rama, for example, joined four years before her father finally created his own profile. Having observed (and been part of) the development of the platform and its usage, youth demonstrated a sense of authority on the site relative to their parents, who often struggled to understand the utility of its various functions. When he began using Facebook, Karim had trouble grasping what to post where. For instance, he repeatedly addressed specific friends in the space for general comments on a photograph. Because he did not 'tag' the friend in question, notifying the user that he had mentioned them, Karim's personalized questions often remained unanswered, hidden among the comments his photograph had inspired.

Children were socialized into Facebook's various functions both by engaging with their peers on the site and by talking about these interactions. They developed an understanding of Facebook codes of usage through discussions analysing the ways in which interactions on Facebook had unfolded (see Gershon 2010). Children developed a Facebook-specific vocabulary (posting, tagging, messaging, etc.) that made clear the various possible forms and functions of communication on the platform.

These social media skills positioned children in transnational families to take agentive roles in interactions with kin. While telephone conversations and Skype calls with relatives in Dakar were primarily organized by her father, it was Rama who would inform Karim about recent exchanges on Facebook. Unlike calls or chat-based applications such as WhatsApp, which mediate exchanges between dyads or pre-selected groups, Facebook's timeline creates a 'public' space between friends. Rama was thus privy to interactions among family members that did not directly involve her, allowing her to observe exchanges that could later be of interest to her father or other family members who spent less time on the platform than she did. Facebook also allowed her to autonomously initiate interactions with kin, as she did with Abdou, who she had added as a friend following a trip to Dakar in 2012.

But the structural affordances that permitted Rama to engage autonomously with family members are unequally distributed among children in transnational families. Scholarship that celebrates the ways in which internet-based communication facilitates transnationalism has often touted these media as democratic relative to expensive long-distance phone calls, but this evaluation obfuscates the material means that are nonetheless necessary to participate in social media. Maintaining one's Facebook profile requires regular access to a smartphone, tablet or computer. While these are common among youth and adults in Dakar, 
children rarely possess their own devices, leaving them dependent on older people for access to the social media platform. Children in the Senegalese diaspora often have privileged access to Facebook compared with their Senegal-based age-mates.

\section{Constructing cross-cousins}

In many ways, Rama and Abdou's relationship diverged significantly from the behaviours that Senegalese (and anthropologists) commonly associate with cross-cousins. Rama was unfamiliar with the kinship terms jamm and sang. She did not appear aware of the stereotypical forms of teasing that cross-cousins often engage in. Nor did Abdou attempt to recruit her to the role of joking partner, introducing her to this mode of play. Marriage between the two was not a possibility that family members explicitly entertained.

But even if Rama never called Abdou her 'jamm', their close relationship suggests that this kinship relation offered a logical foundation for the creation of new forms of relatedness, linking them across the Senegalese diaspora. The particularity of Abdou and Rama's relationship is further illustrated through comparison with Abdou's relationship with one of his parallel cousins in Dakar, Coumba, who was two years younger than Rama. Coumba was born in France, but when her parents divorced her mother sent her to live with her grandmother in Dakar. As his parallel cousin, Coumba was Abdou's rakk bu jigeen or younger sister. Abdou took up this role of an older sibling by directing and disciplining her. He also regularly gave her small gifts, snacks and pocket money when he visited their grandmother's house. But Coumba never received gifts as substantial as the plane ticket or $€ 200$ he offered Rama. Rama's status as his cross-cousin and visitor from Paris allowed her and Abdou to play with their relative status positions, rendering the age gap that divided them relatively less important to defining their kinship relations.

Rama and Abdou were quick to emphasize their status as cousins, not as uncle and niece. For Rama, this meant that Abdou was not a person of her father's generation who had the right to boss her around. For Abdou, the concept of jamm/ sang cross-cousins provided him with a means of creating a close relationship not only with Rama but also with her father. Scholars of kinship have argued that kin strategically use marriage between cross-cousins to cement socioeconomic relations between a nephew and his mother's brother. In Wolof society, men are said to have a material obligation to provide not only for their own children, but also for their sister's children (Diop 1985: 60). John and Jean Comaroff point out that a mother transmits to her children a particular relationship with her brother, which is accompanied by 'ritualized reciprocal exchanges, solidarity against agnatic rivals and, sometimes, substantial material support' (1981: 37). The characteristics associated with the ideal of a relationship between a mother's brother and sister's son render this link particularly advantageous if the mother's brother becomes the father-in-law of his sister's son.

An examination of the efforts Abdou and Karim invested in the creation and maintenance of Abdou and Rama's relationship shows how the cross-cousin model provided a foundation not only for a close relationship between Abdou and Rama but also between Abdou and Karim. Abdou's mother had four other living brothers, but, to my knowledge, he did not offer any of their daughters 
gifts as substantial and frequent as those he provided Rama. The Comaroffs note that, although a man's mother is likely to have multiple brothers, he will 'generally emphasize his close matrilateral link with only one or two of them', carving out his own kinship universe by 'selectively activating a number of linkages' (Comaroff and Comaroff 1981: 33). Kinship relations are always negotiable, produced through individuals' efforts to position themselves within political-economic networks of kin. The significance of Abdou's relationship with Rama was the result of her role as her father's daughter, his uncle. In cross-cousin relations she held the high status of sang thanks to this relation, essentially representing and yielding the authority of his uncle.

Establishing a close relationship with Rama and, by extension, with her father, Karim, allowed Abdou to create and reinforce socio-economic bonds with this French-educated branch of their transnational family. Like his uncle, Abdou's formal education in Dakar had provided him with access to salaried employment in the formal economic sector. His plans to emigrate to Quebec would reinforce parallels between the two men's lives and statuses in their family, as educated migrants to francophone destinations who had the means to migrate legally and seek skilled jobs abroad.

Indeed, as tightening immigration controls and economic decline in 'fortress Europe' have caused France's allure to stagnate among French-educated Senegalese, Canada has recently gained in popularity and prestige as a migration destination (see Newell 2012; Hirtzmann 2013; Pâris 2014). Quebec has seen an upsurge in visa requests from young French citizens who hope to relocate to this francophone area that is perceived to have rebounded more quickly than Europe following the 2008 financial crisis (Daudens 2012; Shingler 2014). Abdou's migration destination thus offered economic promise and prestige similar to that which was likely associated with France when his uncle migrated in the 1970s. Abdou's and Karim's education and class status distinguished them from their relatives who had migrated to work in the informal economic sector in Spain or Italy, as well as from others who were unemployed in Dakar. Abdou's choice to cultivate a close socio-economic relationship with Rama and her father both flows from and reinforces divisions in the Senegalese diaspora that may be observed within their own transnational family.

For his part, Karim played a strategic role in reinforcing, broadcasting and supporting the kinship behaviours that linked his daughter and nephew. He verbally highlighted the material support that Abdou provided Rama, as well as the affection she displayed for Abdou. Even if her father never spoke of marriage, Karim frequently teased his daughter about her relationship with Abdou, repeatedly stating in a sing-song tone that she loves her cousin. Drawing frequent attention to the gifts the cousins exchanged, Karim circulated an image of closeness between the two, reminding his daughter and other family members that she and Abdou share a special bond. Karim also paid for the gift that she offered Abdou on their trip to Dakar, treating Rama as the gift's impetus and true giver. He demonstrated a willingness to finance the plane ticket that Abdou had promised his daughter, transforming a verbal proposition from Abdou to Rama into a material debt between his nephew and himself. He also defended Abdou to Rama, assuring her that her cousin would make good on his promise to buy her a ticket to Dakar. In facilitating the acts of exchange that linked the two cousins, Karim actively worked to reproduce Abdou and Rama's close 
relationship. And yet it was on Facebook, with Rama, that the majority of their interactions were carried out, giving the girl a sense of authorship in the creation of this relationship.

Bourdieu emphasized the fact that kinship relations can always be characterized in multiple ways (traced through paternal or maternal lines, for example), so that 'one can always bring a remote relative closer ... by emphasizing what unites', or 'distance the closest relative by emphasizing what separates' (1990: 172). As individuals manage and manipulate the meanings and practices of kinship for personal and collective aims, what is at stake 'is nothing other than the definition of the practical limits of the group' (ibid.: 172). The identification and redefinition of the terms of a cross-cousin relationship, key to individuals' positions in socioeconomic networks, simultaneously mark boundaries of belonging between differently positioned groups of kin.

Abdou's gifts to Rama thus provided a means by which he could carve his own political-economic position in their transnational family, cultivating closeness through tacit reference to jamm/sang relationships without explicitly characterizing the relationship as such. These repeated material exchanges created privileged socio-economic links between Abdou, Karim and Rama, but avoided the sometimes stigmatizing connotations of cousin marriage. They wove particularly dense connections between the francophone, educated members of their transnational family, by reconfiguring long-standing kinship behaviours in ways that allowed them to position themselves as 'modern' individuals, capable of integrating in Europe or North America. In so doing, Abdou, Karim and Rama carved out new forms of kinship in the Senegalese diaspora through reference to and transformation of kinship norms readily recognizable in Dakar.

Rama's obliviousness to the workings of cross-cousin relationships in Senegal was relatively inconsequential, given that the two men, both raised in Dakar, actively facilitated gift exchanges between the two cousins. Her father's and cousin's acquaintance with the cross-cousin relation made 'possible effective forms of tropic improvisation' (Agha 2007: 340), which organized and provided moral justification for the flow of material resources. As the recipient of Abdou's material care, Rama was the locus of her father's and cousin's efforts at making and reinforcing their transnational connections. The two men thus established a cultural scaffolding surrounding her, aimed at creating a particular closeness between these two geographically distant branches of their transnational family.

\section{Conclusion}

An analysis of Abdou and Rama's relationship as that of 'transnational crosscousins' sheds light on the ways in which individuals in the Senegalese diaspora draw on and reconfigure long-standing modes of kinship in new political economic contexts and through new media. By engaging in certain kinship behaviours associated with jamm and sang relations, without explicit use of these kin terms, Abdou was able to draw on this kinship relation to connect with certain transnational kin without associating himself with the 'traditional' practice of cousin marriage. Decoupling kinship behaviours and kinship terms, these transnational kin improvised on the jamm/sang relationship in ways that allowed them to position themselves favourably in Senegal and abroad. 
The interactions in transnational Senegalese families examined here have revealed the ways in which children actively participate in the reproduction of transnational kinship relations and how caregivers attempt to guide children's interpretations of family by establishing cultural scaffolding around them. Facebook provides an efficient means through which to carry out this scaffolding, by giving children particular agency in the reproduction of kinship relations. Because Rama actively maintained her relationship with Abdou, the efforts her father and Abdou put into establishing a closeness between the cousins were easily overlooked. As such, Rama and her 'love' for her cousin appeared to be the origin of this closeness.

The autonomy and agency Facebook grants children in transnational kinship relations are not evenly distributed across transnational families. Indeed, Facebook allows children with regular access to the social media platform, who are thus already privileged, to create and reinforce relations that accentuate extant inequalities between themselves and their Senegal-based age-mates. But viewed through the lens of economic moralities of rank-based redistribution, reinforcing these inequalities, as Abdou did with his substantial gifts, is not in itself problematic, in that a more substantial difference of rank might motivate more significant redistribution of resources later on. Rama's position of privilege is not problematic in that it might eventually direct the flow of resources, if (and only if), through these exchanges, Abdou and Karim also transmit key concepts of economic moralities of rank-based redistribution, so that her unequal position might one day move her to invest in their Senegal-based family. Investments in children of migrants are uncertain but are critical to the social and material reproduction of families in Senegal. These investments are also a gamble, increasing inequalities that can benefit transnational family members only if they are also accompanied by a transmission of economic moralities that treat migrants' privileged status as requiring the redistribution of resources to family in Africa.

\section{Acknowledgements}

Sincere thanks to Caroline Bledsoe, Robert Launay, Jennifer Cole, William Murphy, Fréderique Fogel, Natacha Collomb, Hannah McElgunn, Amélie Grysole, Dinah Hannaford, Ismaël Moya, Hélène Neveu Kringelbach and the three anonymous reviewers for their helpful comments on this article. I also thank the Senegalese families in Paris and Dakar who welcomed me into their homes and their 'Facebook families'. Earlier versions of this article were presented at the 2016 American Anthropological Association annual meeting, the EHESS seminar 'Appellatifs: référence et adresse dans les relations de parenté, and Northwestern's Program of African Studies graduate seminar. The research for this article was supported by a dissertation fieldwork grant and Osmundsen award from the Wenner-Gren Foundation for Anthropological Research, Hans E. Panofsky and Morris Goodman awards from Northwestern University's Program of African Studies, and research awards from Northwestern University's Buffett Institute, the Centre EdgarMorin and the Institut Interdisciplinaire d'Anthropologie du Contemporain (IIAC).

\section{References}

Agha, A. (2007) Language and Social Relations. Cambridge: Cambridge University Press. 
Anderson, B. (2013) Us and Them: the dangerous politics of immigration control. Oxford: Oxford University Press.

APS (2015) 'Le secteur informel représente 41,6\% du PIB (officiel)', Agence de Presse Sénégalaise (APS), 14 April.

Bankston, C. L. (1998) 'Youth gangs and the new second generation: a review essay', Aggression and Violent Behavior 3 (1): 35-45.

Bledsoe, C. (1990) "No success without struggle": social mobility and hardship for foster children in Sierra Leone', Man 25 (1): 70-88.

Boehm, D. A. (2012) Intimate Migrations: gender, family, and illegality among transnational Mexicans. New York NY: NYU Press.

Bourdieu, P. (1990) The Logic of Practice. Palo Alto CA: Stanford University Press.

Bruna, K. R. and K. Gomez (eds) (2009) The Work of Language in Multicultural Classrooms: talking science, writing science. New York NY: Routledge.

Bruner, J. S. (1978) 'The role of dialogue in language acquisition' in A. Sinclair, R. Jarvella and W. J. M. Levelt (eds), The Child's Conception of Language. New York NY: Springer.

Buggenhagen, B. (2012) Muslim Families in Global Senegal: money takes care of shame. Bloomington IN: Indiana University Press.

Carsten, J. (2000) Cultures of Relatedness: new approaches to the study of kinship. Cambridge: Cambridge University Press.

Cissé, M. (2005) 'Langues, État et société au Sénégal', Sudlangues 5: 99-133.

Coe, C. (2011) 'What is love? The materiality of care in Ghanaian transnational families', International Migration 49 (6): 7-24.

Coe, C. (2014) The Scattered Family: parenting, African migrants, and global inequality. Chicago IL: University of Chicago Press.

Coe, C., R. R. Reynolds, D. A. Boehm, J. M. Hess and H. Rae-Espinoza (eds) (2011) Everyday Ruptures: children, youth, and migration in global perspective. Nashville TN: Vanderbilt University Press.

Cole, J. (2011) 'A cultural dialectics of generational change: the view from contemporary Africa', Review of Research in Education 35 (1): 60-88.

Cole, J. (2016) 'Giving life: regulating affective circuits among Malagasy marriage migrants in France' in J. Cole and C. Groes (eds), Affective Circuits: African migrations to Europe and the pursuit of social regeneration. Chicago IL: University of Chicago Press.

Cole, J. and D. L. Durham (eds) (2008) Figuring the Future: globalization and the temporalities of children and youth. Santa Fe NM: School for Advanced Research Press.

Comaroff, J. L. and J. Comaroff (1981) 'The management of marriage in a Tswana chiefdom' in E. J. Krige and J. L. Comaroff (eds), Essays on African Marriage in Southern Africa. Cape Town: Juta.

Daudens, F. (2012) 'Les jeunes français se ruent vers le Québec', ICI Radio Canada, 1 December <https://ici.radio-canada.ca/nouvelle/589792/immigration-pvt-francais>, accessed 28 July 2018.

Déchaux, J. H. (2003) 'La parenté dans les sociétés occidentales modernes: un éclairage structural', Recherches et Prévisions 72 (1): 53-63.

Dial, F. B. (2008) Mariage et divorce à Dakar. Paris: Karthala.

Diop, A. B. (1985) La Famille Wolof. Paris: Karthala.

Durham, D. (2000) 'Youth and the social imagination in Africa: introduction to Parts 1 and 2', Anthropological Quarterly 73 (3): 113-20. 
Durham, D. (2004) 'Disappearing youth: youth as a social shifter in Botswana', American Ethnologist 31 (4): 589-605.

Foley, E. (2009) Your Pocket Is What Cures You: the politics of health in Senegal. New Brunswick NJ: Rutgers University Press.

Fox, R. (1967) Kinship and Marriage: an anthropological perspective. Cambridge: Cambridge University Press.

Gershon, I. (2010) 'Breaking up is hard to do: media switching and media ideologies', Journal of Linguistic Anthropology 20 (2): 389-405.

Gibson, J. (1979) The Ecological Approach to Visual Perception. London: Houghton Mifflin.

Gillis, J. R. (1996) A World of their Own Making: myth, ritual, and the quest for family values. Cambridge MA: Harvard University Press.

Gulløv, E., C. Palludan and I. Wentzel Winther (2015) 'Engaging siblingships', Childhood 22 (4): 506-19.

Hannaford, D. (2016) 'Intimate remittances: marriage, migration, and MoneyGram in Senegal', Africa Today 62 (3): 92-109.

Hashim, I. and D. Thorsen (2011) Child Migrants in Africa. London: Zed Books for the Nordic Africa Institute.

Hirtzmann, L. (2013) 'Les Français s'exilent de plus en plus au Québec', Le Figaro, 1 January <http://www.lefigaro.fr/international/2013/01/01/0100320130101ARTFIG00150-les-francais-s-exilent-de-plus-en-plus-au-quebec.php>, accessed 29 July 2018.

Hondagneu-Sotelo, P. and E. Avila (1997) "'I'm here, but I'm there": the meanings of Latina transnational motherhood', Gender and Society 11 (5): 548-71.

Hunleth, J. (2011) 'Beyond on or with: questioning power dynamics and knowledge production in "child-oriented" research methodology', Childhood 18: 81-93.

Irvine, J. (2001) 'Style as distinctiveness: the culture and ideology of linguistic differentiation' in P. Eckert and J. R. Rickford (eds), Style and Sociolinguistic Variation. Cambridge: Cambridge University Press.

Keane, W. (2013) 'Secularism as a moral narrative of modernity', Transit: Europäische Revue 43: 159-70.

Latour, B. (1993) We Never Were Modern. Cambridge MA: Harvard University Press.

Launay, R. (1977) 'Joking slavery', Africa 47 (4): 413-22.

Launay, R. (2006) 'Practical joking', Cahiers d'Études Africaines 46 (4): 795-808.

Lévi-Strauss, C. (1945) 'L'Analyse structurale en linguistique et en anthropologie', Word: Journal of the Linguistic Circle of New York 1 (2): 1-21.

Maira, S. and E. Soep (eds) (2005) Youthscapes: the popular, the national, the global. Philadelphia PA: University of Pennsylvania Press.

Manning, P. (2012) Semiotics of Drink and Drinking. New York NY: Continuum.

Maurer, B. (2009) 'Moral economies, economic moralities: consider the possibilities!' in K. E. Browne and B. L. Milgram (eds), Economics and Morality: anthropological approaches. New York NY: Altamira.

Mauss, M. (1928) 'Parentés à plaisanteries' in Annuaire 1927-1928. Paris: École Pratique des Hautes Études, Section des Sciences Religieuses.

Melly, C. (2011) 'Titanic tales of missing men: reconfigurations of national identity and gendered presence in Dakar, Senegal', American Ethnologist 38 (2): 361-76. 
Miller, D., E. Costa, N. Haynes, T. McDonald, R. Nicolescu, J. Sinanan, J. Spyer, S. Venkatraman and X. Wang (2016) How the World Changed Social Media. London: UCL Press.

Morgan, D. (1996) Family Connections: an introduction to family studies. Cambridge: Polity Press.

Moya, I. (2017) De l'argent aux valeurs: femmes, économie, société à Dakar. Nanterre: Éditeur Publications de la Société d'Ethnologie.

Neveu Kringelbach, H. (2016) 'The paradox of parallel lives: immigration policy and transnational polygyny between Senegal and France' in J. Cole and C. Groes (eds), Affective Circuits: African migrations to Europe and the pursuit of social regeneration. Chicago IL: University of Chicago Press.

Newell, S. (2012). The Modernity Bluff: crime, consumption, and citizenship in Côte d'Ivoire. Chicago IL: University of Chicago Press.

Ochs, E. and B. Schieffelin (2009) 'Language acquisition and socialization: three developmental stories and their implications' in A. Duranti (ed.), Linguistic Anthropology: a reader. Chichester: Wiley-Blackwell.

Ochs, E. and T. Kremer-Sadlik (eds) (2013) Fast-forward Family: home, work, and relationships in middle-class America. Berkeley CA: University of California Press.

Olwig, K. F. (1999) 'Narratives of the children left behind: home and identity in globalised Caribbean families', Journal of Ethnic and Migration Studies 25 (2): 267-84.

Orellana, M. F., B. Thorne, A. Chee and W. S. E. Lam (2001) 'Transnational childhoods: the participation of children in processes of family migration', Social Problems 48 (4): 572-91.

Pâris, M. (2014) “"Ruée vers l'Ouest”: le Québec, c'est vraiment l'eldorado?', L'Obs: Rue89, 15 February <http://rue89.nouvelobs.com/blog/quebecoscope/ 2014/02/15/rueevers-louest-le-quebec-cest-vraiment-leldorado-232314>, accessed 29 July 2018.

Parreñas, R. (2001) 'Mothering from a distance: emotions, gender, and intergenerational relations in Filipino transnational families', Feminist Studies 27 (2): 361-90.

Portes, A. and R. G. Rumbaut (2001) The Story of the Immigrant Second Generation: legacies. New York NY: Russell Sage Foundation.

Portes, A. and M. Zhou (1993) 'The new second generation: segmented assimilation and its variants', Annals of the American Academy of Political and Social Science 530 (1): 74-96.

Radcliffe-Brown, A. R. (1940) 'On joking relationships', Africa 13 (3): 195-210.

Radcliffe-Brown, A. R. and D. Forde (1950) African Systems of Kinship and Marriage. New York NY: Routledge.

Schmalzbauer, L. (2001) 'Searching for wages and mothering from afar: the case of Honduran transnational families', Journal of Marriage and Family 66: 1317-31.

Shingler, B. (2014) 'Montreal's French invasion: why immigrants from France are moving en masse', Globe and Mail, 14 October <http://www.theglobeandmail. $\mathrm{com} /$ news/national/montreals-french-invasion-whyimmigrants-from-france-aremoving-in-en-masse/article21085397/>, accessed 29 July 2018.

Thorsen, D. (2006) 'Child migrants in transit: strategies to assert new identities in rural Burkina Faso' in C. Christiansen, M. Utas and H. E. Vigh (eds), Navigating Youth, Generating Adulthood: social becoming in an African context. Uppsala: Nordiska Afrikainstitutet. 
Versluys, E. (2010) Langues et Identités au Sénégal. Paris: L’Harmattan.

Yount-André, C. (2017) 'Giving, taking, and sharing: reproducing economic moralities and social hierarchies in transnational Senegal'. PhD thesis, Northwestern University.

\begin{abstract}
Scholarship on transnational families has regularly examined remittances that adults abroad send to children in their country of origin. This article illuminates another permutation of these processes: family members in Senegal who establish relations with and through children in France through gifts and money. Focusing on relationships between children in Paris and their family members in Dakar, it provides an insight into the everyday exchanges through which transnational families attempt to assure the material reproduction of households in Africa. I trace the ways in which children use Facebook to maintain relationships with relatives in Senegal and examine how adults shape these relations. Focusing specifically on innovative forms of 'cross-cousin' relationships in the Senegalese diaspora, this article illustrates how adults create cultural scaffolding around children who may be unaware of the kinship terms for the relationships in which they are implicated. I demonstrate how practices that have permitted Africans to weather economic volatility for centuries are now carried out, in part, through social media. Approaching material circulation and the transmission of cultural values as mutually imbricated processes, I demonstrate how Senegalese selectively reinforce links with certain family members, in an attempt to favourably position themselves in socio-economic networks of transnational kin.
\end{abstract}

\title{
Résumé
}

Les recherches menées sur les familles transnationales ont régulièrement étudié les transferts d'argent entre adultes à l'étranger et enfants restés dans leur pays d'origine. Cet article met en lumière une autre permutation de ces processus : les membres d'une famille au Sénégal qui nouent des relations avec des enfants en France ou par leur intermédiaire au moyen de cadeaux et d'argent. En se concentrant sur les relations entre des enfants à Paris et des membres de leur famille à Dakar, l'article apporte un éclairage sur les échanges quotidiens par lesquels les familles transnationales tentent d'assurer la reproduction matérielle des foyers en Afrique. L'auteur s'intéresse à la manière dont les enfants utilisent Facebook pour entretenir les relations avec des proches au Sénégal et examine la manière dont les adultes façonnent ces relations. En se concentrant spécifiquement sur les formes innovantes de relations de "cousinage " au sein de la diaspora sénégalaise, cet article illustre la manière dont les adultes créent un échafaudage culturel autour des enfants qui ne connaissent pas toujours les termes de parenté applicables aux relations dans lesquelles ils sont impliqués. L'auteur démontre comment les pratiques qui ont permis aux Africains de surmonter la volatilité économique pendant des siècles s'exercent aujourd'hui en partie à travers les médias sociaux. Abordant la circulation matérielle et la transmission des valeurs culturelles comme des processus mutuellement imbriqués, l'auteur démontre comment les Sénégalais renforcent sélectivement les liens avec certains membres de leur famille, pour tenter de se positionner favorablement dans les réseaux socioéconomiques de parenté transnationale. 